\title{
女性ワルチン腫瘍症例の検討
}

\author{
河田了・四/宮 隆・安田 範夫* \\ 久 育男・村上 泰
}

\section{Nine Case Reports of Warthin's Tumor in Women}

\author{
Ryo Kawata, Takashi Shinomiya, Yasuo Hisa and Yasushi Murakami \\ (Kyoto Prefectural University of Medicine) \\ Norio Yasuda \\ (Kyoto First Red Cross Hospital)
}

\begin{abstract}
One hundred two patients with parotid tumor were treated in the ENT Department, Kyoto Prefectural University of Medicine between 1989 and 1994. Twenty-four of the 102 parotid tumors were Warthin's tumor (adenolymphoma). This incidence of Warthin's tumor was higher than that in any previous reports. This and other recent reports show that the incidence of Warthin's tumor has tended to increase recently, but the reason for this increase is not clear. In general, it is said that Warthin's tumor is found much more frequntly in males than in females, so we reviewed and analyzed 9 clinical cases of Warthin's tumor found in women. The average age of these women was approximately 10 years younger than that of male patients. No substantial differences were seen between male and female cases of Warthin's tumor on CT and Echo findings.
\end{abstract}

Key words : Warthin's tumor, parotid tumor, female

\section{はじめに}

耳下腺に発生する良性腫瘍のらち最も多いものは多形 腺腫であり, 次に多いワルチン腫瘍(腺リンパ腫)はこれ よりずっと少ない，井上ら1)の報告によると，本邦15施 設1390例のらちワルチン腫瘍は7.3\%，海外10施設 6935

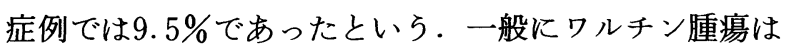
中高年の男性に多く発生するとされているが，その女性 の発生頻度は 5 〜 31\%と報告されている2) 5).

ワルチン腫瘍は, 病理学的に, リンパ組織と上皮性組 織からなることから単形腺腫に分類することに異論もあ るが，1972年に発表された WHO 分類6)では腫瘍組織内 に存在するリンパ組織は腫瘍ではないといら観点から単 形腺腫として分類されている.
今回, 我々は平成元年から 6 年の間に 9 例の女性ワル チン腫瘍症例を経験したので，若干の文献的考察も含め て報告する。

\section{症 例}

平成元年 1 月から平成 6 年 12 月までの間の当科におけ る耳下腺手術症例は102例であり (図 1 ), そのらちワル チン腫瘍症例は 24 例 $(23.5 \%)$ で， 万ち女性症例は 9 例 （8.8\%)であった(表 1). 以下その 9 症例を呈示する(表 2 ).

症例 1 :

72歳，女性. 1 力月前に右耳下部の腫瘤に気づいた. 腫瘤は弾性軟で自発痛, 圧痛なく癒着, 顔面神経麻痺も 


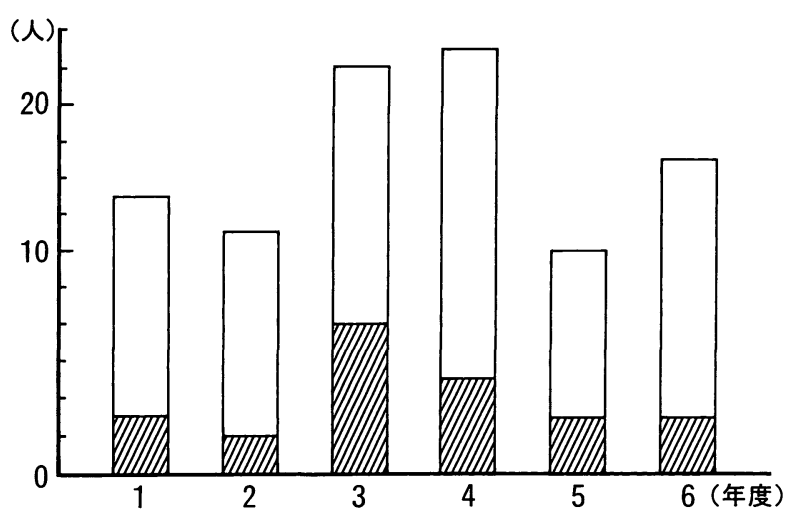

図 1 平成元年 1 月から平成 6 年12月までの耳下腺腫瘍手術症 例. 斜線部はワルチン腫瘍症例を示す.

\section{表 1 耳下腺腫瘍症例の病理組織診断} WHO 分類 $(1972$ 年)による.

I. epithelial tumours

A. adenomas

1. pleomorphic adenoma (mixed tumour) $15 \quad 41 \quad 56$

2. monomorphic adenomas

$\begin{array}{lrrr}\text { a) adenolymphoma } & 15 & 9 & 24 \\ \text { b) oxyphilic adenoma } & 0 & 0 & 0 \\ \text { c) other types } & 0 & 0 & 0\end{array}$

B. mucoepidermoid tumour $2 \quad 2 \quad 4$

C. acinic cell tumour

1001

D. carcinomas

1. adenoid cystic carcinoma

2. adenocarcinoma

000

3. epidermoid carcinoma

224

4. undifferentiated carcinoma $\quad 1 \quad 001$

022

$\begin{array}{lllll}\text { 5. carcinoma in pleomorphic adenoma } & 2 & 1 & 3\end{array}$ (malignant mixed tumour)

II. non-epithelial tumours

$\begin{array}{lll}4 & 3 & 7\end{array}$

計

$42 \quad 60 \quad 102$

認めない、ェコー検査では，耳下腺浅葉に大ささが 12 $\times 14 \times 19 \mathrm{~mm}$ の腫瘍を認め, 内部が低エコーで境界が 明瞭な良性パターンを示した. CT では耳下腺浅葉に単 純でややhigh densityな massを認め, 造影でも en-
表 2 女性ワルチン腫瘍 9 症例

FNA で(ー)は細胞成分が採取できなかったことを示す。

\begin{tabular}{c|c|c|c|c|c}
\hline 症例 & 年齢 & 悪性徵候 & 大きさ & ${ }^{99 \mathrm{~m} T c}$ & FNA \\
\hline 1 & 72 & $(-)$ & $12 \times 14 \times 19$ & & ワルチン \\
2 & 51 & $(-)$ & $14 \times 18 \times 25$ & & 腺様豪胞癌 \\
3 & 57 & $(-)$ & $15 \times 15 \times 24$ & & リンパ組織 \\
4 & 68 & $(-)$ & $15 \times 20 \times 20$ & hot & ワルチン \\
5 & 49 & $(-)$ & $30 \times 35 \times 40$ & hot & ワルチン \\
6 & 69 & $(-)$ & $35 \times 45 \times 50$ & hot & $?$ \\
7 & 30 & $(-)$ & $20 \times 20 \times 20$ & hot & $(-)$ \\
8 & 53 & $(-)$ & $15 \times 15 \times 20$ & & ワルチン \\
9 & 52 & $(-)$ & $20 \times 25 \times 30$ & & $(-)$
\end{tabular}

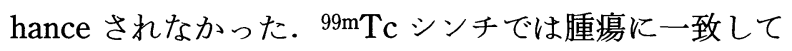
欠損像が認められた. FNA ではワルチン腫瘍と診断さ れた。手術は耳下腺浅葉切除術が施行され, 腫瘍は粘稠 な液体を含むとともに，実質部分も認められた，病理診 断はワルチン腫瘍であった.

症例 2 :

51歳, 女性. 1 力月前に左耳下部の腫瘤に気づいた. 腫瘤は弾性硬で, 自発痛, 圧痛なく癒着, 顔面神経麻痖 も認めない. ェコー検查では, 耳下腺下極に大きさが $25 \times 14 \times 18 \mathrm{~mm}$ の腫瘍を認め, 内部エコーが不均一で 境界がやや不明瞭な腫瘍を認めた. CT では耳下腺下極 に単純でややlow density な massを認め, 造影では ring 状に enhance された. ${ }^{99} \mathrm{~m} \mathrm{Tc}$ シンチでは腫瘍に一 致して久損像が認められた. FNA では腺様囊胞癌疑い との診断であった. 手術は耳下腺浅葉摘出術, 拉よび上 頸部郭清術が施行され, 腫瘍は充実性であった. 病理診 断は腺様囊胞癌ではなくワルチン腫瘍であった。

症例 3 :

57歳, 女性. 6 年前に右耳下部の腫瘤に気づいたが放 置していた。腫瘤は弾性硬で, 自発痛, 圧痛なく癒着, 顔面神経麻㿁も認めない、エコー検査では, 耳下腺浅葉 に大きさが $24 \times 15 \times 15 \mathrm{~mm}$ の腫瘍を認め, 内部がやや 不均一で境界がやや不明瞭であった. CT では耳下腺浅 葉に単純でやや high density な mass を認め, 造影では

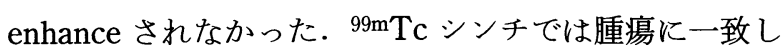
て欠損像が認められた. FNA では lymphoid tissue と の回答であった. 手術は耳下腺浅葉切除術が施行され, 腫瘍の割面は概して充実性であったが一部粘稠な液体を 含むcystic な部分を認めた。病理診断はワルチン腫瘍 であった. 


\section{症例 4：}

68歳，女性. 1 力月前に左耳下部の腫瘤に気づいたが 放置していた。腫瘤は弾性硬で, 自発痛, 圧痛なく癒着, 顔面神経麻痺も認めない.エコー検査では, 耳下腺浅葉 に大きさが $20 \times 20 \times 15 \mathrm{~mm}$ の腫瘍を認め, 内部が均一 で境界は明瞭であった．CT では耳下腺浅葉に単純でや や high density な mass を認め, 造影では enhance され

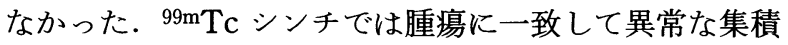
が認められた. FNA ではワルチン腫瘍と診断された。 手術は耳下腺浅葉切除術が施行され，腫瘍の割面は概し て充実性であったが一部粘稠な液体を含むcystic な部 分を認めた．病理診断はワルチン腫瘍であった。

症例 5 :

49歳, 女性. 1 年前に左耳下部の腫瘤に気づいたが放 置していた。腫瘤は弾性硬で, 自発痛, 圧痛なく癒着, 顔面神経麻痺も認めない.エコー検査では, 耳下腺浅葉 に大きさが $40 \times 35 \times 30 \mathrm{~mm}$ の腫瘍を認め, 内部がやや 不均一で境界は明瞭であった. CT では耳下腺下極に単 純でややhigh densityな massを認め, 造影では

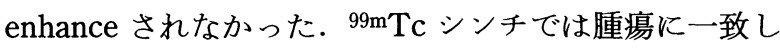
て明らかな集積が認められた．FNA ではワルチン腫瘍 と診断された. 手術は耳下腺浅葉切除術が施行され, 腫 瘍の割面は充実性であったが一部粘稠な液体を含む cystic な部分を認めた．病理診断はワルチン腫瘍であっ た.

\section{症例 6 :}

69歳, 女性. 5 年前に右耳下部の腫瘤に気づいたが放 置していた，若干の増大傾向あり。腫瘤は弾性軟で, 自 発痛, 圧痛なく癒着, 顔面神経麻痺も認めない。エュー 検査では，耳下腺浅葉に大きさが $45 \times 50 \times 35 \mathrm{~mm}$ の腫 瘍を認め, 内部が均一で境界も明瞭であった。CTでは 耳下腺浅葉に単純でやや high density な mass を認め,

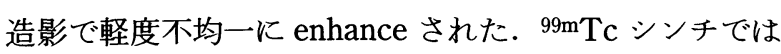
腫瘍に一致した異常な集積が認められた．FNAでは悪 性所見のない上皮系細胞から成って括り，良性腫瘍と考 えられたが，それ以上の診断は不可能であった。手術は 耳下腺浅葉切除術が施行され，腫瘍の割面は充実性であ ったが一部漿液性液体を含む cystic な部分を認めた。 病理診断はワルチン腫瘍であった.

症例 7 :

30歳, 女性. 1 年前に左耳下部の腫瘤に気づいたが放 置していた。腫瘤は弾性硬で, 自発痛, 圧痛なく癒着,
顔面神経麻痺も認めない。エュー検査では，耳下腺浅葉 に大ささが $20 \times 20 \times 20 \mathrm{~mm}$ の腫瘍を認め, 内部が均一 で境界も明瞭であった。CT では耳下腺浅葉に単純でや や high density な mass を認め, 造影で ring 状に enhance された。 ${ }^{99 \mathrm{~m}} \mathrm{Tc}$ シンチでは腫瘍に一致した異常な集積が 認められた. FNA では粘液状の液体が採取されたが, 細胞成分がほとんどなく，診断不可能であった．手術は 耳下腺浅葉切除術が施行され，腫瘍の割面は充実性であ ったが一部粘稠な液体を含む cystic な部分を認めた。 病理診断はワルチン腫瘍であった。

症例 8 :

53歳，女性. 6 力月前に左耳下部の腫瘤に気づいたが 放置していた，弾性軟で，自発痛，圧痛なく癒着，顔面 神経麻痺も認めない.エコー検査では, 耳下腺浅葉に大 きさが $15 \times 15 \times 20 \mathrm{~mm}$ の大きさの腫瘍を認め，内部が 均一で境界も明瞭であった。 CT では耳下腺浅葉に単純 でやや high density な mass を認め, 造影で enhanceさ れなかった． ${ }^{99 \mathrm{~m}} \mathrm{Tc}$ シンチでは腫瘍に一致して異常な集 積は認められなかった. FNA ではワルチン腫瘍と診断 された. 手術は耳下腺浅葉切除術が施行され，腫瘍の割 面は充実性であったが一部粘稠な液体を含む cystic な 部分を認めた．病理診断はワルチン腫瘍であった。

症例 9 :

52歳，女性. 1 年前に右耳下部の腫瘤に気づいたが放 置していた。腫瘤は弾性硬で, 自発痛, 圧痛なく瘉着, 顔面神経麻痺も認めない。エュー検査では, 耳下腺下極 に大きさが $25 \times 30 \times 20 \mathrm{~mm}$ の腫瘍を認め, 内部が均一 で境界も明瞭であった．CT では耳下腺下極に単純でや や high density な mass を認め, 造影ではやや enhance

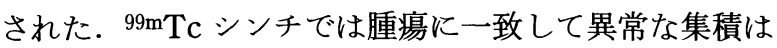
認められなかった．FNA では細胞成分を採取できなか った. 手術は耳下腺浅葉切除術が施行され，腫瘍の割面 は充実性であった. 病理診断はワルチン腫瘍であった.

\section{考察}

ワルチン腫瘍の頻度は, 井上ら1)の集計によると, 耳 下腺腫瘍手術症例中わが国では7.3\%，外国では9.5\%で あると報告している.

当科では平成元年から平成 6 年までの 6 年間に 102 例 の耳下腺手術症例を経験したがそのらちワルチン腫瘍症 例は24例(23.5\%)であり上記の報告より頻度が高い(図 1, 表 1)。しかし, 国内外ともにワルチン腫瘍症例は 
近年増加傾向にあるという．入義られによると、ワルチ ン腫瘍の全耳下腺腫瘍に対する頻度は1961年から1980年

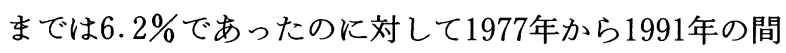
では15.3\%に増加しているといら. 井上ら1) も同様に 1977年から1981年と1982年から1986年で比較し, 前群は $5.7 \%$ ，後群は $13.5 \%$ であると述べている. その原因と して，はっきりしたことは不明であるが，1)高齢化社 会および高齢者に対しても安全な麻酔，手術が行えるよ らになった，2)画像診断の発達とともにより確実な診 断が可能になった，3)耳鼻咽喉科医が積極的に頭頸部 外科手術を行らようになった，4)患者の病識が向上し たなどがあげられる。

ワルチン腫瘍が男性に好発することはよく知られてい るが，これまでの報告では，男性の割合は69\%から95\% と圧倒的に高率である1) 5)8). 当科ではワルチン腫瘍 24 例中15例が男性 (62.5\%)，女性が 9 例 (37.5\%)であった (表 1 ). 以上 6 施設の報告と当科の症例をまとめると, ワルチン腫瘍141例中女性症例は27例(19.1\%)であった. 男性症例の場合，入院手術をする時間がないといら患者 もしばしばあり経過観察している症例もある。したがっ て実際にはも5少し男性に頻度が高いものと考兄られる。

またワルチン腫瘍は中高年に好発するとされ，井上 $ら^{1)}$ は25例の平均が 63.6 歳, 成田 ${ }^{4)}$ は20例の平均が 64.1 墄と報告している. 今回ワルチン腫瘍女性 9 症例の 平均は55.7歳であり, 若干若い傾向がみられた(表 2 ).

それに対して男性症例15例の平均は61.0歳であった。大 井ら ${ }^{9)}$ は本邦92例のワルチン腫瘍の統計をとっているが, それによると男性は中高年に集中して発生しているのに 対して，女性は若年から高齢者までまんべんなく発生し ていたと報告している. 今回当科の症例でも同様な傾向 がみられた(図 2).

99m Tc シンチグラフィーによって hot nodule を示すも のは, 耳下腺腫瘍では, 線条導管細胞由来の腫瘍とされ るワルチン腫瘍, oncocytoma, mucous producing papillary adenocarcinoma の 3 者だけとされている1011). ワルチン腫瘍は $99 \mathrm{~m} \mathrm{Tc}$ を取り込んで hot noduleを示す とされているが，村上 ${ }^{12)}$ はその $82 \%$ が hot noduleであ ったと報告している。しかし，今回検討した女性ワルチ ン腫瘍症例では ${ }^{99 \mathrm{~m}} \mathrm{Tc}$ で hot nodule を呈したるのは 9 例中 4 例のみであった．男性症例15例では 8 例が $99 \mathrm{~m} \mathrm{Tc}$ に括いて hot noduleを呈した。いずれも村上の報告よ り低率であるが，男女差はないものと考えられた。 また

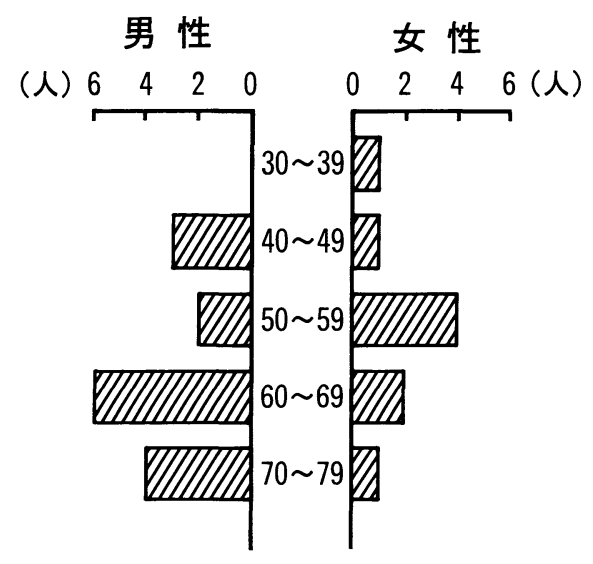

図 2 ワルチン腫瘍症例の性別および年龄分布

腫瘍の充実成分と囊胞成分の比率と ${ }^{99 \mathrm{~m}} \mathrm{~T} \mathrm{c}$ の取り込みの 関係は, 今回の 9 症例に限っていえば無関係であった. その他の画像診断, すなわちCT, エューについても検 討したが，いずれも性差を認めなかった。

ワルチン腫瘍の成因として, 北村ら ${ }^{13)}$ は以下の説が あるとまとめている。それによると，1）リンパ節ない しリンパ組織内唾夜腺組織の異所性増殖, 2 ) 咽頭上皮 の異所増殖, 3 ) 鰓性異所発生, 4 ) Orbital inclusion, 5 ) 異所性胸腺細胞, 6) リンパ節内被細胞の異常増殖, 7 ) 唾液管拡張説，8 ) Oncocyte 説，9)慢性刺激による 退行現象をあげている. そのらち最も考えらる成因とし て Albrecht \& Arzt が提唱した 1)の説が有力である. その後も多くの研究者がその説を支持している. しかし この説にも問題点は残されている.つまり, リンパ節内 で導管上皮が増殖を続ければ，腫瘍が大きくなればリン パ組織成分は減少するはずである.ところが実際には上 皮性腫瘍成分とリンパ組織成分の比はほぼ一定である. 浸潤しているリンパ球が腫瘍細胞か否かが問題であるが, 腫瘍性のものでないとする説が有力である14115)。 したが って, リンパ球増殖は反応性のものと考兄られるが，そ の原因に対して決定的な説は今のところない.

\section{まとめ}

1) 平成元年 1 月から平成 6 年 12 月までの 6 年間に, 耳下腺手術症例102例のらち24例がワルチン腫瘍と診断 され，そのらち9例が女性症例であった。これは従来の

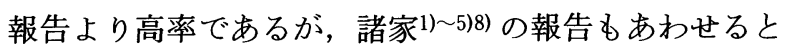
近年女性症例は増加傾向にあった。 
2 ）男性症例は中高年に多くみられたが，女性症例は 若年から高齢者までまんべんなくみられ，平均年齢は男 性症例と比較して約10歳若かった。

3 ）画像診断では, 男性症例と女性症例に差異を認め なかった。

\section{文 献}

1 ）井上俊哉, 山下敏夫, 辻川覚志, 他 : 当教室 10 年間に括け る耳下腺腫瘤の統計. 耳鼻臨床 $82 ： 245 \sim 250,1989$.

2 ）更級則夫, 岡本美孝, 宮崎総一郎, 他 : 当教室 20 年間の耳 下腺腫湯の臨床統計. 耳鼻臨床 補57 : 172 177, 1992.

3 ）岩崎幸司, 石崎久義, 峯田周幸, 他: 大唾夜腺腫湯の臨床 統計的観察. 耳鼻臨床 補 $60: 64 \sim 71,1992$

4 ）成田七美, 吉原俊雄, 篠 昭男, 他 : 当教室に和数る大唾 液腺腫瑒の臨床統計.耳鼻 $39:$ 1004 1009, 1993.

5 ）古川勝朗, 白神か㧍り, 中島智子, 他：両側性飞発生した 耳下腺多形腺腫例. 耳鼻臨床 88 : 59 63, 1995 .

6) Thackray AC and Lucas RB: Tumors of the major salivary glands. In Atlas of Tumor Pathology. pp 56 59, Armed Forces Institute of Pathology, Washington DC, 1974.

7 ）入義典子, 原田輝彦, 山田弘之, 他：両側耳下腺 Warthin 腫瘍の 5 症例. 耳喉頭頸 $66: 457 \sim 462,1994$.

8 ）谷垣内由之, 奥田 稔, 坂口幸作, 他 : 耳下腺 adenolym- phoma 9 症例の検討. 耳喉 $57: 103 \sim 107,1985$.

9 ）大井益一, 三吉康郎, 大山 勝, 他: Warthin 腫瘍の 2 症 例. 耳鼻臨床 $71: 1091 \sim 1100,1978$.

10）嶋田文之，金子敏郎，北村 武，他：Technetium $99 \mathrm{~m}(99 \mathrm{~m}$ Tc) とよる耳下腺腫瘍の診断. 耳鼻臨床 64 増 : 1271 1277, 1971.

11) Noyek AM : Radionuclide salivary scan imaging of a "functioning” malignant parotid tumor (mucous-producing papillary adenocarcinoma). J Otolaryngol $11: 83 \sim 85,1982$.

12) 村上 泰 : 耳下腺腫瘍の術前診断. 耳下腺腫瘍の臨床(奥 田 稔編). 87 124頁, 医学教育出版, 東京, 1984.

13）北村 武, 戸川 清 : Papillary cystadenoma lymphmatosum (Warthin's tumor) その臨床及び成因について.耳 喉 $35:$ 189 195, 1963.

14) David JB : Evans' Histological Appearances of Tumors, 3rd Edition. pp 538 540, Churchill, Livingston, 1978.

15）小田島哲世: 電顕腫瘍病理学 (小野江為則編). 309頁, 南 山堂, 東京, 1982.

$$
\left.\begin{array}{l}
\text { 原稿受付 : 平成 } 7 \text { 年 } 4 \text { 月 } 3 \text { 日 } \\
\text { 原稿採択 : 平成 } 7 \text { 年 } 5 \text { 月 } 17 \text { 日 } \\
\text { 別刷請求先 : 河田 了 } \\
\text { 干602 京都市上京区河原町通広小路上ル梶井町 } 465 \\
\text { 京都府立医科大学耳鼻咽喉科学教室 }
\end{array}\right)
$$

